\title{
Blended Learning Analysis in Nature Basic Concept in Elementary School Teacher Education Study Program
}

\author{
Fine Reffiane ${ }^{1}$, Sudarmin 2 , Wiyanto ${ }^{3}$, AP Budi Prasetyo ${ }^{4}$ \\ ${ }^{1,2,3,4}$ Graduate School, Universitas Negeri Semarang, Indonesia \\ Corresponding email: reffianefine@gmail.com
}

\begin{abstract}
Blended learning is an appropriate lesson in today's era of rupture and globalization. It is a kind of learning that combines face-to-face learning in the classroom and online learning through students' smartphone / computers. The problem in this research was to know how far students' understanding about blended learning. The purpose of this study was to describe the extent to which students' understanding of blended learning. The research method used was descriptive qualitative with the subject of students who were listed in the course Nature Basic Concept in the Elementary School Teacher Education (PGSD) program in Semarang PGRI University. The results obtained showed that $60 \%$ of students understood blended learning, $20 \%$ of students understood enough about blended learning and $30 \%$ of students did not understand blended learning. It could be concluded that in general, the students who followed the Nature Basic Concept in PGSD study program in Semarang PGRI University needs learning activities that connect the concept of face-to-face learning and online learning so that they can receive well the learning process.
\end{abstract}

Keywords: Blended learning, Nature Basic Concept

\section{Introduction}

Blended learning is a learning method that combines face to face with harmonious online material. A mix of conventional training in which trainers and trainees meet directly with online training that can be accessed anytime, anywhere, 24 hours a day, 7 days a week. These description must arise questions and confusion in ourselves. To answer this, you can find many articles of this type of learning. From the existing studies, the biggest e-learning is direct interactivity between learners and instructors. Commonly, the learning is a two-way process. Same as conventional learning, feedbacks are given to participants from teachers and others who invent feedbacks for participants. In this way learning outcomes will be more effective and on target.

This answers that e-learning programs in many companies do not always get satisfactory results. A thousand materials are abundant and are available in full. People can also study anytime and anywhere. It can be from the office, home, hotel, or at the cafe as long as they are connected via wireless network. However, still the level of the use of e-learning materials is relatively low. In simple analysis, people need friends and need immediate feedback. Just as we feel in conventional training in the classroom.
The continued obstacle of e-learning is creating the impression of loneliness that one can not last long in learning. In half an hour, someone is lazy enough and not too motivated to continue learning. It is not because the material which is not good or the online system of the material presented is less interactive, but people feel that they are alone and need others. Nevertheless, this is not a reason for a true learner. However, the facts show that people cannot last long in the computer.

The problem of this study was about students' understanding of blended learning. The type of research used was qualitative research (Maida et al. 2017). For more, blended learning is usually done through live discussions using audioconferencing, interactive video conferencing, realtime chat consoles, and various variations. Learning materials can be downloaded and learned in advance in form of texts, audios and videos. In addition to this learning, the writers happened to do this learning and can ask directly with the instructor of the materials, consult for an idea and understanding, and build personal closeness. Although never meeting face to face, the writers and the other participants felt that they had a direct affinity with the instructor. This can happen because participants interacted directly, even if only through virtually connected 
communication signals. In doing this, each other provides support, feedback and suggestions for the progress of others. (Lalima and Lata Dangwal 2017)

Blended e-learning is now widely used by open and long distance education providers. In the past, only the Open Universities were allowed to conduct distance education, but now in Indonesia, it is possible with the issuance of the decree of the Minister of National Education No.107 / U / 2001 (2 July 2001) on the implementation of Higher distance education programs, certain universities have the capacity to provide education open and long distance using blended e-learning, has also been permitted to run it. Non-formal education institutions such as courses have also taken advantage of this blended e-learning advantage for its programs. (Alzahrani and O'Toole 2017)

Specifically, in blended e-learning, teachers require to understand the following principles. Blended e-learning is the delivery of information, communication, education, trainings on teacher training materials, both the substance of subject matter and educational science online. This learning provides a set of tools that can enrich conventional learning values (conventional learning models, studies contain textbooks, CDROMs and computer-based training) so that its participants are hoped to be able to answer the challenges of the development of globalization.

Blended e-learning does not mean replacing conventional learning models in the classroom, but strengthening the learning model through content enrichment and educational technology development. Teachers' capacity varies greatly depending on the form of content and delivery. The better the harmony between the content and the delivery tools with the learning style, the better the capacity of students which in turn will give better results. (Gambari, A.I; Shittu, A. T; Ogunlade, O.O; Osunlade 2017).

Obviously, blended learning utilizes electronic technology services. It is where teachers and students, students and fellow students or teachers and fellow teachers can communicate with relative ease without being limited by protocol matters. This can be realized by utilizing the benefits of computers (digital media and computer networks). On the one hand, teachers can also use independent teaching materials (selflearning materials) which are stored on a computer so that it can be accessed by teachers and students anytime and anywhere. Also, blended learning utilizes lesson schedules, curriculum, learning progress and things related to educational administration that can be seen at any time on the computer. (Studies and Bilgiler 2017)

\section{Methods}

This study used qualitative descriptive analysis method. The population used were students of elementary school teacher education in $2^{\text {nd }}$ and $4^{\text {th }}$ semester. The study took place in odd semester of the 2017/2018 school year. Meanwhile, the research site was at the one of University located in the East of Semarang, Semarang City. For more, the number of students were 60 male students and 100 female students.

\section{Results and Discussion}

The use of technology such as the internet is seen to be helpful in the delivery of learning along with its content, and it seems to overcome the limitations of time and space or place on conventional learning face to face. However, not all applications of this kind of technology can all solve the problem immediately, rather how the process, management and presentation strategy of learning appear to have a significant impact on the quality of learning itself.

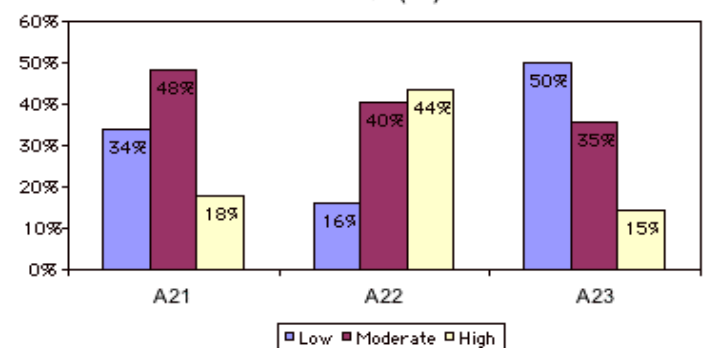

Firgure 1. Graph of students' understanding of blended learning

Education and the Internet, according to John Chamber, CEO of Cisco System Inc., are two influential equalizers in the last decade. With the Internet, people's behaviours in working, learning, playing or socializing have changed. They prefer to interact through online media such as chatting, social media, and blogs or microblogs like Twitter and others. Likewise in learning, the term commonly heard in learning with the internet is e- 
learning, online learning, or Internet learning. (Meltem Eryilmaz 2015)

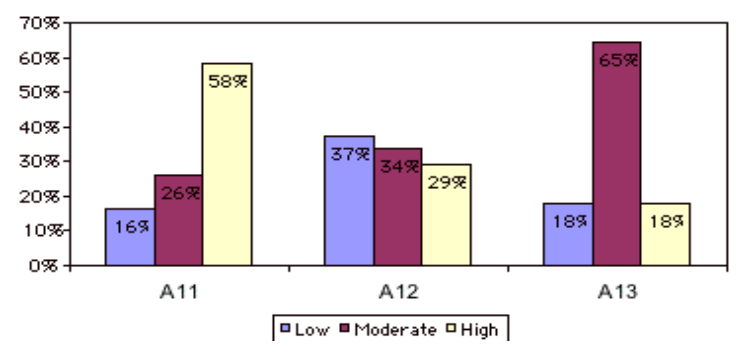

Figure 2. Graph of students' interest in blended learning

In semester 2 and 4 there were a lot of students, but they did not understand the meaning of blended learning. They still felt comfortable with a conventional learning system

A strategy of learning model development that combines online learning and conventional or face-to-face, commonly referred to as blended learning, is expected to help universities that have not applied e-learning technology widely so that the opportunity to get a quality education can be felt also by students or students at College.

\section{Conclusions}

The results obtained are $65 \%$ students understand about blended learning, 20\% of students understand enough about blended learning and $30 \%$ of students do not blended learning. Therefore, it can be generalized the
PGSD study program students in Semarang PGRI university require learning activities that connect the concept of face-to-face learning and online learning so that they can receive well the learning.

\section{References}

Alzahrani, Majed Gharmallah, and John Mitchell O'Toole. (2017). The Impact of Internet Experience and Attitude on Student Preference for Blended Learning. Journal of Curriculum and Teaching 6(1), 65.

Gambari, A.I; Shittu, A. T; Ogunlade, O.O; Osunlade, O.R. (2017). Effectiveness Of Blended Learning And E-Learning Modes Of Instruction On The Performance Of Undergraduates In Kwara State, Nigeria.Pdf. Malaysian Online Journal of Education Science. 5(1), 25-36.

Lalima, Dr., and Kiran Lata Dangwal. (2017). "Blended Learning: An Innovative Approach." Universal Journal of Educational Research. 5(1), 129-36.

Maida, Carl A. et al. (2017). Qualitative Methods in the Development of a Parent Survey of Children's Oral Health Status. Journal of Patient-Reported Outcomes. 2(1), 7.

Meltem, E. A. (2015). The Effectiveness Of Blended Learning Environments. Contemporary Issues In Education Research - 4th Quarter. 8(4), 6. 